\title{
The Coming Together of Astronomy and Economics ${ }^{1}$
}

The coming together of astronomy and economics is an unusual and paradoxical event, no doubt, but nevertheless not entirely random. This can be seen in personal aspects, characterising the minds of individuals of many talents and broad interests, and certain forms of contact between these two fields of knowledge in terms of subject-matter. The latter are only sensed today and certainly have not been fathomed yet. Anyway, as regards individuals, there are many examples, and some are very fine indeed. Two such examples shall be discussed below, although there are more.

In 1526, Sigismund I the Old, King of Poland, resolved to embark on a massive reform of the currency system, which had been prepared since the beginning of his reign and was to encompass the entire realm. The reform, highly desirable for political reasons, was to put an end to the intolerable currency situation that had arisen with time in various lands subject to his rule. The situation was particularly grave in the lands of Prussia, where throughout the 15th century and later, until the first decades of the next century, the state of currency left much to be desired. It was bad during war, but in peace it time it was not much better either. There were widespread complaints about the high prices that were encountered in all areas of life. People complained not only about the high

1 Translated from: R. Knapowski, Skojarzenie się astronomii z ekonomiq, in: Opuscula Casimiro Tymieniecki septuagenario dedicata, 1959, pp. 128-142 by Tomasz Żebrowski and proofread by Stephen Dersley and Ryszard Reisner. The translation and proofreading were financed by the Ministry of Science and Higher Education under 848/2/P-DUN/2018. 
prices of gold and silver but also food, servants' and workers' wages, and everything that they needed and used. The reason behind all this was the cheapness of money, a fact of which people at large were not aware, or to be precise, the process of money becoming ever cheaper or being constantly debased or, to put it bluntly, falsified.

In the Prussian lands, also covering former Polish Pomerania, silver shillings or solidi had circulated in the times of the Teutonic Order since 1380, that is, two years before the death of Winrich von Kniprode, the most powerful of the Order's Grand Masters, as the basic unit of the local monetary system. Originally, 134 pieces were coined out of one Chełmno mark ( grzywna weighing $191 \mathrm{~g}$ ), the fineness of which was 131/3 łut of silver (831/3\%). Since a computational mark was always held to have 60 shillings, one mark by weight yielded almost 21/4 computational marks. Later, in particular in the 15th century, the coin was subjected to continuous devaluation, losing both its weight (by over 20\%) and fineness. As a result, when out of one mark over 700 shillings were finally coined, this meant that over 11 computational marks were obtained out of it. In the meantime, during the Thirteen-Years War with the Order, the Prussian cities of Gdańsk (Danzig), Toruń (Thorn) and Elbląg (Elbing), which surrendered to the Polish king, also coined shillings of no better weight or fineness. Towards the end of the 15th century, during the times of Grand Master Johann von Tiefen, then a Polish vassal, admittedly, the coining of completely discredited shillings stopped, but they stayed in circulation. In their place, the Teutonic Order's grosz began to be issued with the face value of three former shillings. It, too, slowly lost its value.

The table, drawing on the work by F.A. Vossberg Geschichte der Preußischen Münzen und Siegel von frühester Zeit zum Ende der Herrschaft des Deutschen Ordens, ${ }^{2}$ rightly called the classic work of Teutonic numismatics, shows currency relations in the Prussian lands to 1519.

2 A. Vossberg, Geschichte der Preußischen Münzen und Siegel von frühester Zeit zum Ende der Herrschaft des Deutschen Ordens, Berlin 1843. 


\begin{tabular}{|c|c|c|c|c|c|c|c|c|c|}
\hline \multirow{2}{*}{ 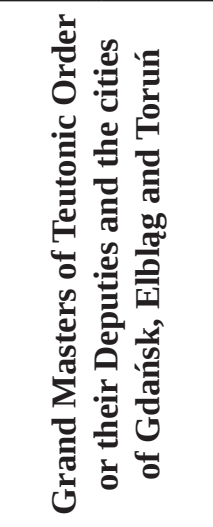 } & \multirow{2}{*}{ 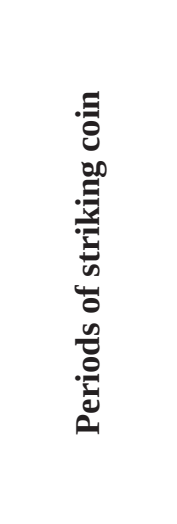 } & \multirow[b]{2}{*}{ 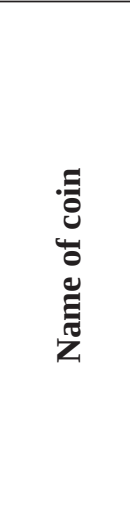 } & \multirow{2}{*}{ 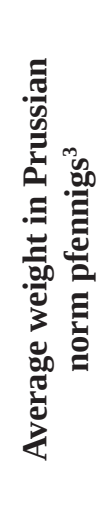 } & \multirow{2}{*}{\multicolumn{2}{|c|}{ 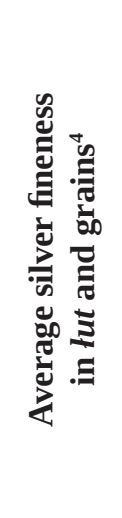 }} & \multicolumn{4}{|c|}{$\begin{array}{c}\text { Coins struck out of } \\
\text { one Chełmno mark } \\
\text { or } 1 / 2 \text { pound of } \\
\text { pure silver }\end{array}$} \\
\hline & & & & & & 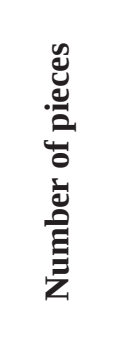 & & 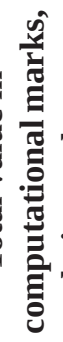 & 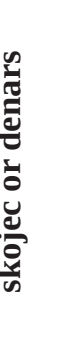 \\
\hline \multirow{2}{*}{$\begin{array}{l}\text { Winrich von } \\
\text { Kniprode }\end{array}$} & \multirow{2}{*}{ 1380-1382 } & \multirow{2}{*}{ shillings } & $0.116^{7}$ & 13 & $6^{5}$ & $134.4^{5}$ & 2 & 5 & $23^{5}$ \\
\hline & & & 0.109 & 13 & $91 / 2$ & 142 & 2 & 8 & \\
\hline $\begin{array}{l}\text { Konrad von } \\
\text { Rothenstein }\end{array}$ & 1382-1390 & shillings & 0.113 & 13 & 3 & 145,8 & 2 & 10 & 9 \\
\hline $\begin{array}{c}\text { Konrad von } \\
\text { Jungingen }\end{array}$ & $1393^{6}-1407$ & shillings & 0.113 & 11 & 14 & $156^{1 / 6}$ & 2 & 10 & 14 \\
\hline \multirow{2}{*}{$\begin{array}{l}\text { Ulrich von } \\
\text { Jungingen }\end{array}$} & \multirow{2}{*}{$1407-1410$} & \multirow{2}{*}{ shillings } & 0.114 & 11 & & 161 & 2 & 16 & \\
\hline & & & 0.114 & 10 & 12 & $1713 / 4$ & 2 & 20 & 21 \\
\hline \multirow{3}{*}{$\begin{array}{l}\text { Heinrich von } \\
\text { Plauen }\end{array}$} & 1410-1411 & shillings & - & 7 & 9 & $260^{1 / 5}$ & 4 & 8 & \\
\hline & 1411-1413 & shillings & 0.107 & 6 & 12 & $292^{4} / 5$ & 4 & 21 & \\
\hline & 1413 & shillings & 0.111 & 10 & - & 187.2 & 3 & 2 & 26 \\
\hline $\begin{array}{l}\text { Herman Gans } \\
\text { (deputy) }\end{array}$ & 1413 & shillings & 0.111 & 7 & 12 & 245.6 & 4 & 2 & 7 \\
\hline \multirow{6}{*}{$\begin{array}{l}\text { Michael von } \\
\text { Sternberg }\end{array}$} & \multirow{2}{*}{1414} & \multirow{2}{*}{ shillings } & 0.113 & 6 & 17 & 261.9 & 4 & 8 & \\
\hline & & & 0.108 & 6 & 3 & 312.9 & 5 & 5 & 5 \\
\hline & 1414-1416 & shillings & 0.104 & 4 & $31 / 2$ & 479.5 & 8 & - & - \\
\hline & \multirow{3}{*}{ 1416-1422 } & \multirow{3}{*}{ shillings } & 0.116 & 8 & & 210.8 & 3 & 12 & 10 \\
\hline & & & 0.105 & 8 & 12 & 231.3 & 3 & 20 & 15 \\
\hline & & & 0.112 & 8 & 9 & $219^{8} / 11$ & 3 & 16 & - \\
\hline
\end{tabular}

3 So-called Richtpfennige.

$4100 \%$ fineness $=16$ lut of 18 grams each

51 computational mark = 24 skojec worth 30 denars each.

6 Konrad von Wallenrod, Grand Master between 1391 and 1393, probably did not strike any shillings because there were enough in circulation. 


\begin{tabular}{|c|c|c|c|c|c|c|c|c|c|c|}
\hline \multicolumn{2}{|c|}{$\begin{array}{l}\text { Paul von } \\
\text { Russdorf }\end{array}$} & $1422-1441$ & shillings & 0.111 & 8 & $37 / 9$ & 229 & 3 & 19 & 18 \\
\hline \multicolumn{2}{|c|}{$\begin{array}{c}\text { Konrad von } \\
\text { Erlichshausen }\end{array}$} & 1442-1449 & shillings & 0.112 & 8 & $21 / 2$ & 229.5 & 3 & 19 & 24 \\
\hline \multirow{2}{*}{\multicolumn{2}{|c|}{$\begin{array}{l}\text { Ludwig von } \\
\text { Erlichshausen }\end{array}$}} & & shillings & 0.104 & 5 & $81 / 2$ & 367,5 & 6 & 3 & - \\
\hline & & 1454-1467 & shillings & 0.099 & 3 & 17 & $5351 / 2$ & 8 & 22 & 6 \\
\hline \multirow{4}{*}{ Cities } & Gdańsk & \multirow{4}{*}{ 1457-1466 } & \multirow{4}{*}{ shillings } & 0.095 & 3 & 12 & 600 & 10 & - & - \\
\hline & Elbląg & & & 0.097 & 3 & $12^{1 / 2}$ & 584 & 9 & 17 & 8 \\
\hline & \multirow{2}{*}{ Toruń } & & & 0.099 & 3 & 16 & 543 & 9 & 1 & 6 \\
\hline & & & & 0.096 & 3 & 2 & 705.5 & 11 & 16 & 6 \\
\hline \multicolumn{2}{|c|}{$\begin{array}{c}\text { Heinrich von } \\
\text { Plauen (deputy) }\end{array}$} & $\begin{array}{l}14 \\
14\end{array}$ & shillings & 0.093 & 3 & $16^{1 / 2}$ & 574 & 9 & 13 & 18 \\
\hline \multicolumn{2}{|c|}{$\begin{array}{l}\text { Heinrich von } \\
\text { Richtenberg }\end{array}$} & 1470 & shil & 0.097 & 3 & 14 & 570 & 9 & 12 & - \\
\hline \multicolumn{2}{|c|}{$\begin{array}{l}\text { Martin von } \\
\text { Welzhausen }\end{array}$} & 1477 & shillings & 0.092 & 3 & 4 & 705 & 11 & 5 & - \\
\hline \multirow{2}{*}{\multicolumn{2}{|c|}{$\begin{array}{c}\text { Johann von } \\
\text { Tiefen }\end{array}$}} & & shillings & 0.092 & 3 & 4 & 705 & 11 & 5 & - \\
\hline & & & & 0.109 & 8 & 6 & 230 & 11 & 10 & - \\
\hline \multicolumn{2}{|c|}{$\begin{array}{l}\text { Frederick of } \\
\text { Saxony }\end{array}$} & 1498-1510 & shillings & 0.100 & 8 & 3 & 256 & 12 & 16 & - \\
\hline \multirow{2}{*}{\multicolumn{2}{|c|}{$\begin{array}{c}\text { Albrecht of } \\
\text { Branden-burg }\end{array}$}} & 1511-1514 & & 0.100 & 8 & $-^{5}$ & 258 & 12 & 185 & $-^{7}$ \\
\hline & & 1515-1519 & & 0.100 & $73 / 4$ & $-^{5}$ & 266 & 13 & 65 & - \\
\hline
\end{tabular}

Faced with such a currency situation as the one that arose in 1519, Nicolaus Copernicus, at that time a canon and administrator of the Warmian Chapter, wrote the first of his two economic treatises, namely Treatise on coins (Tractatus de monetis) and On the estimation of the coin (De estimatione monete). Both are short (they consist of only three or six pages) but significant. The latter is an elaboration on the former. Both give a correct description of the minting methods used hitherto and suggest ways of ameliorating the situation. Copernicus reaches back to the times when a pound of pure silver represented eight computational

7 On the basis of documents, the other figures are based on coins.

$8 \mathrm{Grosz}=1 / 20$ of computational mark 
marks (or four Chełmno marks), with the alloy containing silver and copper in equal shares ${ }^{9}$, next he mentions shillings in which only onefourth was silver and one pound was reckoned to represent 16 computational marks erat in his quarta pars dumtaxat argenti et -arc. XVI libr. argenti continebant, then he provides the alloy proportions and the value of shillings coined by Prussian cities crevit pecunia multitudine autemon bonitate, cepitque IIII partibus eris quinta argenti misceri, donec pro - arc. XX libra argenti purissimi emeretur and finally he makes an emotional statement: Decrescebat ergo in dies magis ac magis estimation pecunie - posterior et pejor semper priori inducta estimationem precedentis oppressit et exrusit, donec estimation solidorum et grossorum valor coequaretur; et marc. XXIIII leves pro libra cedant argenti; necdum cessatur usque in presens. - Quid restat, nisi ut proxime marc. XXVI libra argenti ematur. - Tantis ergo vitiis laborant prussiana moneta - soli aurifices ejus - erumnis fruuntur -; colligunt enim ex promiscua pecunia antiquam, - plus semper argenti cum moneta recipients ab imperito vulgo. Utinam reformentur hec, dum tempus, est, ante ruinam maiorem, ut saltam ad XX marc. libra argenti restitueretur ${ }^{10}$. As the best principle of coining good money, Copernicus thus recommends that it should be coined at one place, not in the name of a single city but the entire country pursuant to an inviolable decree (decreto inviolabili) and that a pound of pure silver should not be reckoned to be an equivalent of more than 20 computational marks. Only after 25 or more years could the coin be renewed.

9 Invenio autem ea numismata, Quue nunc grossi vocantur, ali Quando solidos fuisse et marcas VIII Iibram I habuisse purissimi argenti Copernicus refers to the computational mark with the word marca, while the ounce (Chełmno) mark is referred to as $1 / 2$ pound or 2 given marks as a pound ubicum, Que marca dicetur, numerum intellegi volo; pro pondere vero libram nominabo, Quemadmodum marce II constituuntip sam. cf. in the treatise on coins: octo marcae complectebantur libram unam argenti puri alias feinsilber, hoc est duas marcas unciales.

10 This is the famous rule that Copernicus ascertained, stating that bad money drives out good, formerly and wrongly called Gresham's Law in recognition of Sir Thomas Gresham, a financial agent of Queen Elizabeth I. 
In the autumn of the same year, that is 1519, a war with the Teutonic Order broke out, and Copernicus, who was personally involved in the defence of Olsztyn, stood alongside the Polish king. In order to cover the costs of the war, amounting in cash only to over 574,000 marks, the Grand Master, Albrecht of Brandenburg, ordered that all church silver and gold vessels be confiscated and turned into coins, thereby flooding the Prussian lands with grosze of the worst quality. Coined in 1521 to pay soldiers, eight-grosz coins contained only one łut of silver each, while, there were 528 groszy to a Chełmno mark (i.e. 4,224 groszy as units) of the total value of 2111/5 computational marks. After a truce of four years was agreed in Toruń on 7 April 1521, grosze of the former type of the fineness of $73 / 4$ lut, weighing however slightly less (0.095 instead of 0.100 ; there were 270 pieces to a Chełmno mark of a total value of $13 \frac{1}{2}$ computational marks) continued to be coined so the currency chaos that had reigned for so long in the Prussian lands was by no means averted.

The session of the Sejm held in Grudziądz in March 1522, at which Copernicus read out his treatise at the request of officials and deputies in attendance, did not bring any positive results, however, because the Prussian cities refused to give up the right to mint their own coins they had been granted some time earlier. Only the peace treaty concluded in Kraków on 8 April 1525 and the homage paid by Albrecht, from then on the Duke of Prussia, to the Polish King gave hope for a successful and final regulation of the monetary system. Following these events, Copernicus resolved to elaborate on his second treatise on money and produced a treatise twice as long as the original one, entitled On the minting of coin (Monete cudende ratio), in which historical and theoretic inquiries were expanded upon and practical recommendations were consistently developed and adjusted to the conditions and possibilities created by the new state of affairs.

The new version of the treatise opened with an introduction to the discussion of general issues that included the two famous sentences enu- 
merating four major causes that, as a rule, lead to the destruction of kingdoms: discord, mortality, barrenness of land and corruption of coin (discordia, mortalitas, terre sterilitas et monete vilitas). Unlike the first three causes, which are obvious, the fourth, comprehended only by finer minds, acts perniciously, and not at once, with a single strike, but slowly and secretly, so to speak, (non uno impetu simul, sed paulatim occulta quadam ratione respublicas everlit). In his historical investigations, Copernicus goes back to the times of Konrad von Jungingen, or the times before the Battle of Tannenberg (ante bellum Tanebergense), or even to the times of Winrich, when in this entire period shillings were minted out of an alloy containing three parts of pure silver and one-fourth part of copper, whereas in the times of Heinrich, after the defeat at Tannenberg, shillings contained only three-fifths parts of silver and later even less, since it was only one-fourth part. Copernicus stresses that the pernicious custom of adulterating money has not stopped up to the present day consuetudo sive licencia adulterandi, expilandi et inficiendi monetam cessare non potuit, ec in hunc diem cessat. 'In what state it is today, it is a shame and pity to speak' in quo statu nunc sit, pudet ac dolet dicere. The worth of money has fallen so badly that there are 30 marks to a pound of silver. If the situation is not remedied (si non succuratur), Prussia will be left with only copper coin and foreign trade will collapse in its entirety. Experience teaches us that those countries thrive that have good coin in circulation, while those with worse languish. Where there is good money, there is art, excellent crafts and an abundance of goods, but where debased coin is in use idleness, laziness and slothfulness abound, while the arts and spiritual culture fall into neglect and prosperity is lost Constat preterea ipsa loca, que bona moneta utuntur, artibus et opificibus egregiis nec non et rerum affluencia pollere, ac contra, ubi vilis moneta in usu est, ignavia, desidia ac resupinato ocio tam bonarum atrium quam ingeniorum culturam negligere arque omnium eciam rerum abundantiam interire. An experienced economist and an expert on human nature speaks to us in the following poignant sentences: Nondum 
memoriam hominum excessit frumenta et annonam minori pecuniarum numero in Prussia empta fuisse, cum adhuc bona moneta uteretur, nunc autem ea vilescente omnium rerum, que ad victum et humanum usum pertinent, precium ascendere experimur. Ex quo perspicuum esse potest levem monetam desidiam magis altere, quam paupertati hominum subvenire.

Copernicus sees a way out of the grave situation, continuing to maintain his previous recommendations - relying strongly on the authority of the Polish King — that the coin in the entire territory of Prussia should be unified and fully adjusted to the Polish coin. For this purpose, he recommends that coins for all Prussia be minted in one common mint or, if this cannot be done, that at most two mints be established, one for Royal Prussia and another for Ducal Prussia. In the former case each coin is to bear the insignia of the Prussian lands on one side and those of the Duke of Prussia on the other. On both sides, the insignia are to be surmounted by a royal crown Conduceret itaque, unam et commune esse in tota Prussia officianam monetariam, in qua omnis generis moneta ex uno latere nummismate sive insigniis terrarium prussie signatur ita, ut superne coronam supereminentem habeat, ut ex hoc regni superioritatem recognoscat, ex atlero vero latere ducis prussie insigne pre se ferat, corona regni similitar incumbente. ${ }^{11}$ In the latter case, coins for Royal Prussia would bear royal insignia on one side and those of the Prussian lands on the other, while coins minted for Ducal Prussia would bear royal insignia on one side and ducal insignia on the other. Copernicus stresses that by a royal decree both coins will have to circulate and be acceptable in the entire realm, and adds a meaningful and perspicacious remark: Que res ad animorum concilationem et negociationum communionem non parum ponderis est habitura. Of course, both coins will

11 There are no doubts whatsoever as to the authenticity of this sentence and part of the next which are struck out in a later ink in two surviving manuscripts and were omitted from many editions of Copernicus works. V. Mikołaja Kopernika rozprawy o monecie i inne pisma ekonomiczne w opracowaniu Jana Dmochowskiego, Warszawa 1923, pp. 12, 2; V. ibidem, pp. LXXIX-LXXX. 
have to be of the same grain or alloy, of equal value and estimation and, being closely supervised by the state authorities (vigili cura primatum reipublice), will continuously have to meet the regulations that will be issued. Old coins must be withdrawn without fail so that they do not 'infect' new ones. In an added separate chapter on the ratio of silver to gold, a certain proposal, given by way of an example, merits attention. It suggests adopting the former ratio of these metals as a standard, i.e. 1 to 11, instead of the actual ratio of 1 to 12 , and mint 20 marks out of 11/11 pounds of silver. Then, the Polish and Prussian grosz would equalise completely, and two Prussian marks would have the same value as the Hungarian gold ducat. In his conclusion, Copernicus succinctly reiterates in six points, with the precision that only a great mind is capable of, all his recommendations in the monetary sphere.

Copernicus no doubt aware that the stability of currency depended on sufficiently strong public finance. He did not discuss this question at great length, however, because he was interested in the monetary issues that had been topical for a long time. Nevertheless, he understood and fully appreciated the role of the state and its political stance in money matters. Therefore, he placed great emphasis on the authority of the Polish State and the resolutions adopted on the initiative of its authorities for the estimation of the coin. Putting full trust in the strength and resources of the kingdom, he was able to be convinced that the conditions he set to protect the stability of the value of money could be met. He knew that the principal condition for attaining this goal was a complete renunciation of any profit from minting money Et quod principes utrinque nihil lucre ex monete cussione sentient. Hence such a strong a recommendation: ut involabiter et immutabiliter perpetuo observetur, quod XX marche dumtaxat et non amplius fiant ex libra una puri argenti, dempto eo quod pro expensis opificii deduci oportet and, on the other hand, also a warning: ut caveatur a nimia monete multitudi. For both conditions can be met only if there is sound finance and a strong state. Sufficient and stable state revenue must be supported by specific curren- 
cy, otherwise the value of the revenue will devalue. 'We shall give the King, Our Lord', Copernicus writes in a letter to Feliks Reich, a canon and custodian of the Warmian Chapter, warning against the postponement of the currency reform, 'a lot of money, i.e. chaff but where will the grain go?' (dabimus Regi Domino Nostro grandem pecuniam, id est paleas, grana autem ubi manebunt?).

The great monetary reform made at the behest of Sigismund I the Old was carried out, by and large, in accordance with the recommendations of Copernicus, who actively participated in convocations, discussions and negotiations in person or by mail for many years. The groundwork for the reform was laid in the Constitution for the Prussian lands of 17 July 1526 (Article 31) and the resolutions of convocations in Elbląg of 7 July 1527 and Malbork (Marienburg) of 8 May 1528. In respect of the Crown, the reform was effected by the mint ordinances of 15 October 1526 and 16 February 1528, accompanied by the royal decree of 15 February 1528 that re-introduced the gold coin to Poland. A decision was made and implemented to unify the monetary systems of the Prussian lands and the Crown to the largest possible extent. In particular, it was decided that once old coins had been withdrawn from Prussia, new ones would be minted, namely grosze, shillings and denars with Polish insignia and those of the Prussian lands, and they would be minted only in a newly-opened royal mint in Toruń (this provision could not be implemented in full, and the mints in Gdańsk, Elbląg and Königsberg (Królewiec) continued to operate, the former two with breaks, though). It was further decided that two Prussian marks would constitute one Hungarian florin (ut-duae marcae florenum Hungaricalem constituant) and the Prussian grosz would be equal to the Polish one (ut grossus Pruthenicus Polonicum aequet). As regards fineness, the grosze were to be struck precisely in accordance with the Crown standard, that is, out of an alloy containing 6 łut of silver and 10 łut of copper, or to put if differently, a half-pound Kraków mark would yield 96 grosz; moreover, one Hungarian florin, equal in value to the Polish 
one, was to be an equivalent of $30 \mathrm{grosz}$ (of 18 denars each). However, instead of the latter original ratio, Copernicus recommended the ratio of at least 40 grosz to one florin, since it better corresponded to the reality of that time. ${ }^{12}$ The monetary system in Poland and in the Prussian lands stayed at this level (about 45 grosz), i.e. in a generally good state, for about fifty years . This is yet one more argument for calling those times the Golden Age - as they are commonly known.

The example of Copernicus being capable of applying his mind to various sciences and problems, apparently distant in terms of magnitude and weight, but in fact closely related, was not isolated. Four hundred years later, when the newly founded Republic of Poland witnessed an acute and prolonged currency crisis after the First World War, another kindred mind emerged, one no less inquisitive, and capable of pursuing broader interests.

The origins of the decline of the Polish currency after the First World War can be traced back to the economic and political legacy left to us by the three Partitioning Powers waging war, in particular the most powerful one-the German Empire. Upon the outbreak of war, Germany began to direct an ever-greater share of its available resources towards world-scale political goals. These policies increasingly affected its economy and society, also impacting the Polish state which was taking shape as an independent political entity in the last stage of the Great War. At the end of the occupation, the German mark and the Polish mark were worth more or less half of their face value. Becoming independent, not only formally, in the sphere of currency, but at least maintaining the purchasing power the currency had at the moment of regaining independence, not to speak of the currency returning to its pre-war purchasing power, were expected by the public opinion as an absolutely certain outcome of the new political situation. Things, however, played out differently. As soon as the Treaty of Versailles was signed on 28 June 1919,

12 V. A 1526 letter to Ludwik Decjusz, head of the Kraków mint, drafted by Copernicus or with his participation. 
giving Poland international foundations for its independent existence, the Polish currency started to lose its value in world opinion. By the end of that year most of its value had been lost. The international community must have been well aware of the greatly insufficient cover for the issued notes and coins by the current state revenues. Meanwhile, general political and economic conditions did not offer any prospects for balancing the economy in the near future. The situation should have improved in the following year; at least this is what was expected. After the great military campaigns against Soviet Russia in which the fortunes of the adversaries swung like a pendulum, taking Polish armies to Kiev and the Soviet army to the outskirts of Warszawa, only for the frontline to settle somewhere in between, an armistice followed. The conclusion of a peace treaty with the neighbour to the east was expected to follow soon after. However, this time round too reality did not live up to expectations.

Leaving aside the protracted peace negotiations in Riga and the uncertain outcome of the Silesian plebiscite, the economic effects of the two wars began to be strongly felt only then, forcing the authorities, lacking any appropriate fiscal apparatus, to incur a growing debt to the issuing institution. The conviction, bordering on certainty, that the situation would continue for a long time, had a dispiriting effect on the rate of currency exchange. Figures for the early years of independence illustrate the state of affairs in the currency sphere at that time. The figures come from the work by Edward Taylor Inflacja polska ${ }^{13}$, giving the most thorough picture of these phenomena and problems in terms of their historical course and the applicable theory.

13 E. Taylor, Inflacja polska, Poznań 1926, p. 22. 


\begin{tabular}{|c|c|c|c|}
\hline Date & $\begin{array}{l}\text { Amount of Polish } \\
\text { marks in circulation } \\
\text { (million) }\end{array}$ & $\begin{array}{l}\text { Treasury Debt } \\
\text { in Polish marks } \\
\text { (million) }\end{array}$ & $\begin{array}{l}\text { Dollar rate index } \\
(1914=1)^{14} \text { on last } \\
\text { week of each month }\end{array}$ \\
\hline \multicolumn{4}{|l|}{1918} \\
\hline 11.11 & 880.2 & - & 1.90 \\
\hline 31.12 & $1,023.8$ & 117.8 & 2.14 \\
\hline \multicolumn{4}{|l|}{1919} \\
\hline 28.2 & $1,160.0$ & 315 & 2.53 \\
\hline 30.4 & $1,346.0$ & 575 & 3.62 \\
\hline 30.6 & $1,784.6$ & 1,125 & 3.97 \\
\hline 31.8 & $2,466.6$ & 2,525 & 7.53 \\
\hline 31.10 & $3,723.6$ & 4,375 & 11.41 \\
\hline 31.12 & $5,316.3$ & 6,825 & 26.36 \\
\hline \multicolumn{4}{|l|}{1920} \\
\hline 29.2 & $8,303.3$ & 10,775 & 37.44 \\
\hline 30.4 & $16,027.9$ & 19,375 & 45.90 \\
\hline 30.6 & $21,730.1$ & 27,625 & 33.43 \\
\hline 31.8 & $31,058.8$ & 39,625 & 50.98 \\
\hline 31.10 & $38,456.8$ & 46,925 & 69.77 \\
\hline 31.12 & $49,361.5$ & 59,625 & 137.99 \\
\hline \multicolumn{4}{|l|}{1921} \\
\hline 28.2 & $62,560.4$ & 77,125 & 200.04 \\
\hline
\end{tabular}

Under these conditions, accompanied of course by the soaring prices of all kinds of goods, Prof. Tadeusz Banachiewicz, Director of Kraków Astronomical Observatory, published in the two high-circulation dailies of the day, namely the Głos Narodu and Kurier Warszawski, his programme for improving the monetary situation dated 5 March 1921. The programme is brief and succinct, and sets out in a few sentences a number of ideas which must have sounded very fascinating at that

14 Parity: 1 U.S. dollar $=4.21$ German marks.

15 The value of Partitioning-Power currencies in circulation at the same time was on 11.11.1918: 7,119.8, on 30.09.1919: 10,760.3 (maximum) and on 30.04.1920: 1,372.1 million Polish marks. 
time. First, it makes strongly worded, correct and incontrovertible general comments followed by proposals organized into four points.

Until state expenses are in equilibrium with revenues, it is not possible to maintain a constant value of banknotes. Meanwhile, a stable currency is one of the fundamental conditions of prosperity of the country, because the unsteadiness of the value of money undermines any credit, prevents rational calculation in industry and commerce and, finally, is a major cause of social unrest. It has already become a platitude that to cure a currency, serious reforms in the country's economy are necessary (raising taxes, increasing production, etc.); however, serious reforms need time, while a constant measure of value is needed now.

We see the following way out of the present predicament:

1. The State allows businesses to conclude contracts in 'Polish zlotys' but payable (for the time being) in Polish marks. Actually, Polish zlotys are issued onto the market.

2. The State determines on a regular basis how many marks equal one Polish zloty; this is done by collecting statistics from various locations in Poland for market prices (in marks) of food, cereals, clothing, footwear, coal, iron and gold so that average prices in Polish zloty be constant.

3. The entire budget of the State, taxes and other fiscal fees, railway tariffs, etc. are calculated in Polish zlotys.

4. Subscriptions to a state loan in Polish zlotys are solicited, postal saving unions also accept deposits in Polish zlotys to be paid in and out in Polish marks according to a rate of exchange.

Supplementing the above proposals, to counteract a potentially sharp a fall in prices, Banachiewicz recommended that a farmland tax, railway and postal tariffs and public official salaries be raised from an inordinately low level. The improvement of currency could by no means substitute other reforms aimed at amending the financial situation. The 
sole purpose of the endeavour would be to remove the worst symptoms of the financial ailment. This in turn would facilitate a change to normal economic relations.

Without going into a detailed assessment of the above proposals, this author wishes to observe that it was here that the idea of conducting economic settlements in a currency unit that does not actually exist surfaced for the first time in Polish or possibly even German articles on business matters. In Poland, in 1921, Feliks Młynarski ${ }^{16}$ recommended that the wholesale price index be used as a benchmark for assessing and paying taxes and fees. Later on, the supporters of this kind of currency dualism grew in number, in spite of understandable fundamental objections among both academics and public officials. In Germany, where inflation had not advanced so far until then as it had in Poland (on 1 March 1921, one U.S. dollar was worth 61 German marks), Eugen Schmalenbach, professor at Cologne University, had been demanding since 1921 that balancing be done in gold marks. Two years later, the movement in support of calculating receivables in gold grew so strong that even a number of ministries petitioned the Reichsbank to adopt this solution. ${ }^{17}$ For the time being, however, the idea put forward by Banachiewicz did not meet with much response from the establishment in Poland, because of the prevailing illusion that the unbridled rise of inflation could be stopped without much sacrifice in taxation.

The otherwise important political events that occurred in March 1921, such as the adoption of the Constitution, the conclusion of the Peace of Riga, and the holding of a plebiscite in Silesia, did not affect the state of the currency in any significant manner. Yet, in the middle of that year, the dependence of the Polish mark on the German mark was strongly underscored when the Government of the Reich set out to make the first reparation payments and began purchasing high-priced currencies wherever it could. At the end of September, the Polish mark,

16 F. Młynarski, Reforma ustroju pieniężnego, Warszawa 1921, p. 98.

17 H. Schacht, Die Stabilisierung der Mark, Berlin-Leipzig 1927, pp. 49-50. 
however, sharply rebounded in Poland, owing to a one-off levy announced by the energetic minister of the treasury, Michalski, and soon collected. In June 1922, when the revenue from the levy ceased and a protracted dispute between the Chief of State and the Sejm began, inflation gained fresh impetus, which could hardly be stopped by a gold loan issued by the minster of the treasury, Jastrzębski. The dramatic events that took place at the end of the year did not help the situation either. A table showing the most important figures, again taken from the work by Edward Taylor ${ }^{18}$, gives an idea of how the situation unfolded until early 1923.

\begin{tabular}{|c|c|c|c|}
\hline Date & $\begin{array}{l}\text { Amount of Polish } \\
\text { marks in circulation } \\
\text { (million) }\end{array}$ & $\begin{array}{c}\text { Treasury Debt } \\
\text { in Polish marks } \\
\text { (million) }\end{array}$ & $\begin{array}{c}\text { Dollar rate index } \\
(1914=1) \text { on last } \\
\text { week of each month }\end{array}$ \\
\hline \multicolumn{4}{|l|}{1921} \\
\hline 30.4 & $86,755.3$ & 106,625 & 195.91 \\
\hline 30.6 & $102,697.3$ & 130,625 & 494.28 \\
\hline 31.8 & $133,734.2$ & 158,000 & 666.98 \\
\hline 30.9 & $152,792.1$ & 178,000 & $1,500.71$ \\
\hline 31.10 & $182,777.3$ & 198,500 & 926.75 \\
\hline 31.12 & $229,537.6$ & 221,000 & 702,71 \\
\hline \multicolumn{4}{|l|}{1922} \\
\hline 28.2 & $247,209.5$ & 230,600 & 945.21 \\
\hline 30.4 & $260,553.8$ & 220,000 & 933.85 \\
\hline 30.6 & $300,101.1$ & 235,000 & $1,082.12$ \\
\hline 31.8 & $385,787.5$ & 285,000 & $2,103.98$ \\
\hline 31.10 & $579,927.7$ & 453,500 & $3,200.32$ \\
\hline 31.12 & $793,437.5$ & 675,600 & $4,242.10$ \\
\hline \multicolumn{4}{|l|}{1923} \\
\hline 31.1 & 909,160 & 799,500 & 7,804 \\
\hline
\end{tabular}

Almost two years after the first publication, on 11 February 1923, Banachiewicz repeated his proposals, this time in the Astronomical Year-

18 E. Taylor, Inflacja polska, Poznań 1926, p. 23. 
book of the Kraków Observatory for 1923 and added a few comments. Having observed that the theoretic Polish zloty had been legally introduced (submitted to the Sejm by the minister of the treasury, Władysław Grabski, the programme of financial reform was based on the computational index zloty), he stressed that the implementation of the 'programme' had been only fragmentary so far, and as such could not bring forth expected results and emphasised that the programme could hardly be considered a remedy for the ailment of the treasury. Its purpose was to "alleviate the most unpleasant conditions resulting from the ailment: the impossibility of saving, the difficulty of cost calculating, high prices of many products and foreign currencies, etc.”

With regard to current developments, Banachiewicz was very critical about the 8-percent gold loan because it unnecessarily pegged gold to Polish marks, which was a very appropriate thing to say and corresponded with the prevailing opinion at that time. He attached greater-in a way decisive-importance to deposits in zlotys in saving associations, though he believed gold to be an imperfect measure of value at that time. The reason behind this opinion was the fact that the price (purchasing power) of gold, like that of foreign currencies, was exorbitant in relation to the Polish mark, for quite understandable reasons in the time of inflation. Finally, Banachiewicz censured the government for giving industrialists a loan of several dozen billion marks out of the state levy that had been collected with a great effort. The charge was fully justified; in the situation that prevailed, the loan was tantamount to a donation.

In order to assess Banachiewicz's proposals fairly, it is necessary to account for the feeling that ran through society at that time. The falling value of the currency, a situation that had already lasted for years, and the extremely high prices of all goods had worn the people's patience thin. The Polish mark was becoming ignored and was no longer relied on. Hence, any other legal tender, no matter what legal or theoretic objections it raised, was accepted and used to an increasingly broader extent. Out of the four points of Banachiewicz's proposal, the third was 
no doubt the furthest-reaching and the most radical in its application. It provided for the calculation of the whole state budget, taxes, fees, tariffs, etc. in Polish zlotys or changing the entire public economy to a new measure of value, which actually did not exist as money. The second point was rather of a technical nature, while the other two, important in legal and general economic terms, were as a matter of fact optional.

In public administration, the computational zloty was used in its many varieties (budget zloty, bond zloty, and finally, a zloty for credit indexation and a general indexation of public revenues). In turned out that although it did provide better information on the payment capacity of society than budgets expressed in marks that rapidly became obsolete, and guaranteed that revenues would be raised as planned, it could not protect fiscal money against devaluation before it was expended, when it was still in the state coffers. Therefore, when the Polish mark began its disastrous downward slide in the second half of 1923, to which the disappointment felt by society in the wake of a long and inopportune trip abroad by the minster of the treasury, Kucharski, had greatly contributed, the run to get rid of the legal tender at any price could not be restrained. It was not capable any longer of fulfilling its principal functions as a measure and representation of value, not to mention its function as a means of capitalisation. The use of the theoretic zloty brought about a favourable effect to some extent in 1923, in the final stage of inflation, by forcing policymakers to embark as soon as possible on a comprehensive fiscal and currency reform and make all calculations refer to a stable measure of value, and not a theoretical one this time round.

Analogous events in Germany provided additional guidance on how to proceed. There, too, since passive resistance was resorted to in the Ruhr Valley in the second half of 1923, inflation had reached the stage of currency disaster. At this stage, with the already widespread use of stable measures of value, sometimes very strange but also interesting from a theoretical point of view ${ }^{19}$, the German mark was repudiated, making

19 H. Schacht, op. cit., p. 54 ff. 
the stabilization of the currency and financial reform a matter of urgency. When on November 15th, thanks to credit in the newly-founded Rentenbank and the huge but final credits in the Reichsbank, the Reich's Treasury ceased to incur debt to the latter institution and when on November 20th, the exchange rate of the U.S. dollar reached 4,210,500,000,000 or 4.2 billion German marks and was stabilised at this level by the currency commissioner, Hjalmar Schacht, the German parliament granted far-reaching powers to the Reich's government to improve finances and stabilise the currency on December 8th. Interestingly enough, the President of the Reichsbank, von Havenstein, who denied that there had been any inflation to the very last moment, by claiming that the Reichsbank had never issued more money than 'was demanded', died of a heart failure on that very day.

In Poland, the German example convinced the previously reluctant Sejm, to give the cabinet of Władysław Grabski equally broad but precisely specified powers by the memorable Treasury Improvement and Currency Reform Act of 11 January 1924. ${ }^{20}$ The Polish mark stabilised in the first half of January 1924 at a level of 9.5 (later 9.3) million marks to the dollar, while the State Treasury ceased to incur debt to the issuing institution only on February 1st. The budget was really balanced even later on, that is, only in March 1924. It follows that the currency was stabilised only thanks to the conviction that the budget could and would be stabilised. ${ }^{21}$

It would be fitting to devote a few words to the comparison of the theoretic assumptions adopted for the improvement of a currency by

20 W. Grabski, Dwa lata pracy u podstaw państwowości naszej, Warszawa 1927, p. 26 ff.

21 On 31 December 1923 there were 125 billion Polish marks in circulation, while on 31 March 1924, 596 billion; the State Treasury was indebted on these two days for 111.3 and 291.7 billion Polish marks, respectively. The dollar stood at 1.5 and 2.2 billion Polish marks, respectively. The exchange for zlotys took place after the founding of Bank Polski, as is well-known, at a rate of 1,800,000 Polish marks for 1 zloty. Interestingly, American 'greenbacks' dropped to $1 / 3$ of its value in $1862-1864$, French pay vouchers and territorial mandates in 1790 $1796 / 97$ to $1 / 100$ or $1 / 4000$, respectively, Roman antoninianuses in 215-270 A.D. dropped to $1 / 100$ of their value, while drachmas in Roman Egypt up to 380 A.D., after over four centuries of constant devaluation, fell to $1 / 10,000,000$ of their original value. 
Nicolaus Copernicus and Tadeusz Banachiewicz. Of course, their proposals must be judged in terms of their times, environments and circumstances. However, there are some general aspects that recommend themselves for a joint judgement and enable a comparison. Copernicus's proposal is based on the bad money rule he discovered. In hyperinflation, it might seem that the rule is reversed, that good money drives out bad. As Jan Dmochowski has already rightly observed, this view bears only 'superficial appearances of rightness'. Strong currencies were not in permanent and regular circulation but were assiduously picked out and treasured. However, another objection comes to mind: whereas Copernicus is adamant that bad money must be completely withdrawn from circulation if new good coinage is introduced, Banachiewicz clearly tolerates the currency being in circulation whose rate falls, in spite of the fact that a new one of a stable value has been introduced. However, in this case, too, the antinomy is only apparent. Banachiewicz does not suggest that a new currency should be put into circulation but only that value should be given in a purely theoretic currency, while payment functions are still to be left to the currency in circulation. The potential of this ideal currency, its attractiveness, is so strong in the transition period that it brings about the disappearance of the materially existing but bad money and forces the authorities to conduct a comprehensive reform. It involves, in agreement with the ideas of Copernicus, the withdrawal of a devaluated currency and replacing it with a new one of full value. There are also differences in the size, form and duration of respective inflations. These differences derive also from a different degree of credit development and credit technique. In more recent times, the expunction of indebtedness was thus an important driving force behind and a result of the devaluation of a currency.

More examples of astronomy and economics coming together could be given. To name but a few: Sir Isaac Newton who for many years headed the Royal Mint in London and while holding this office, collected valuable experience on fluctuations in the value of precious met- 
als; Geminiano Montanari, professor of mathematics and astronomy at Bologna and Padua Universities, the author of the 1683 work La zecca in consulta di Stato; ${ }^{22}$ and Alfonso X, King of Castile and Leon, and Germany, who was famous for his Alfonsine Tables (as a student Copernicus always kept them handy), but he was also able to collect taxes with great energy and skill, and derived income from minting money. Finally, he lost all three of his crowns and fled to the Moors. Last but not least, Julius Caesar, who knew the practical side of all fiscal matters very well, introduced gold currency to Rome, wrote a treatise on stars characterised by great accuracy, and he is still remembered by all as the reformer of the calendar.

Are there any deeper subject-matter associations between astronomy and economics? Who can tell with any certainty today? Of course, the alternations of night and day and the changes of seasons are astronomical phenomena, and as such they affect the course of human work and the productivity of earth, and thus the entire economy. But this is not the point. Rather, it would be interesting to know if also other changes and fluctuations spread over a long time, which are so important and characteristic of the general course of economic life, have any connection with the phenomena observed in astronomy. We know of the view held by W. Stanley Jevons, generally rejected by economics, about a causal relationship between the frequency of sunspots and economic crises. In more recent times, Henry Moore attracted attention with his claim that the planet Venus, at 8-year intervals, through terrestrial magnetism, affected the weather and crops. The claim was not definitely opposed by Ernst Wagemann, president of the German Institut für Wirtschaftsforschung. ${ }^{23}$ Generally speaking, in the most recent times, many economists, notably American and Swiss, study the Moon and the Sun intensively to draw conclusions about the presumed effects on the economy of the various periodic phenomena and the impact of these heavenly bodies

22 G. Montanari, La zecca in consulta di Stato, Milan 1683.

23 E. Wagemann, Wirtschaftspolitische Strategie, Hamburg 1937, pp. 46-47. 
on the Earth. The last word on this interesting and perhaps deceptive subject has yet to be said. However, a detailed discussion of specific theories falls outside the scope of this article.

\section{Literature}

Grabski W., Dwa lata pracy u podstaw państwowości naszej, Warszawa 1927.

Mikołaja Kopernika rozprawy o monecie i inne pisma ekonomiczne w opracowaniu Jana Dmochowskiego, Warszawa 1923.

Młynarski F., Reforma ustroju pieniężnego, Warszawa 1921.

Montanari G., La zecca in consulta di Stato, Milan 1683.

Schacht H., Die Stabilisierung der Mark, Berlin-Leipzig 1927.

Taylor E., Inflacja polska, Poznań 1926.

Wagemann E., Wirtschaftspolitische Strategie, Hamburg 1937. 